\section{Leadership and performance in intermunicipal networks}

\author{
Denita Cepiku and Marco Mastrodascio
Management and Law, University of Rome Tor Ver \\ Department of Management and Law, University of Rome Tor Vergata, Rome, Italy
}

Leadership and performance

Abstract

Purpose - The purpose of this research is to highlight the impact of integrative leadership behaviors on network performance in local government networks.

Design/methodology/approach - The data were retrieved from a survey conducted on 362 local government network leaders in Italy. Their leadership behaviors were compared with the level of network performance anonymously self-reported.

Findings - The findings show that high frequency in the usage of a specific category of behavior does not always lead to high performance in local government networks. Moreover, leadership behaviors leading to highly performing networks are not always engaged most frequently by networks' leaders.

Originality/value - This research gives an empirical contribution to a neglected topic: network leadership. Moreover, the authors attempt to highlight how it is able to influence network performance.

Keywords Performance, Leadership, Network

Paper type Research paper

\section{Introduction}

Networks are relatively stable patterns of social relations among interdependent actors. More specifically, networks ought to be interpreted as connective tissue tying together individuals and organizations working toward shared aims and governed through structures of interdependence involving multiple organizations both public and private, where one unit is not merely the formal subordinate of the others in some larger hierarchical arrangement (O’Toole, 1997; Stiver, 2017).

Leadership in networks is viewed as a process aimed at "building trust and mutual understanding and negotiating joint goals" (Huxham and Vangen, 2000, p. 1,171). It is variously labeled as integrative leadership, collaborative leadership, network leadership or interorganizational leadership (Connelly, 2007; Chrislip, 2002; Silvia and McGuire, 2010; Kiefer and Montjoy, 2006; Sun and Anderson, 2012; Alexander et al., 2001; Umble et al., 2005; Vangen and Huxham, 2003).

However, network leadership has been considered to be a Cinderella (Avery, 2004; Mandell and Keast, 2009; Silvia and McGuire, 2010; Baker et al. 2011; Crosby and Bryson, 2017) due to the fact that, for a long time, some peculiarities of networks such as the absence of hierarchical authority, no formal subordination and interaction based on expertise, trust and legitimacy have been translated into the misbelief that networks are leaderless (Lipnack and Stamps, 1994). Consequently, in order to align the interest of the distinct network members with the cooperative whole, strong leadership is necessary (Bryson et al., 2006; Lemaire and Provan, 2010).

The literature has steadily developed on networks management and governance, including coordinating mechanisms, institutional design and performance assessment, due to the complexities that differentiate networks from single-agency structure. In regard to network performance evaluation, the purpose of this research is to contribute to the network

(C) Denita Cepiku and Marco Mastrodascio. Published by Emerald Publishing Limited. This article is published under the Creative Commons Attribution (CC BY 4.0) licence. Anyone may reproduce, distribute, translate and create derivative works of this article (for both commercial and non-commercial purposes), subject to full attribution to the original publication and authors. The full terms of this licence may be seen at http://creativecommons.org/licences/by/4.0/legalcode
Received 1 February 2019

Revised 29 June 2019

7 November 2019

18 January 2020

Accepted 24 January 2020

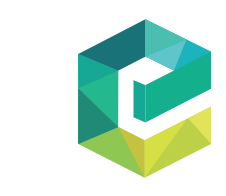

Journal of Public Budgeting, Accounting \& Financial Management Vol. 32 No. 2, 2020 pp. $177-196$

Emerald Publishing Limited DOI 10.1108/JPBAFM-02-2019-0019 
JPBAFM

32,2

performance literature in local government networks by investigating the influence of leadership on six dimensions of performance as mainly cited in the literature: cost savings, service quality improvement, financial incentives, better bargaining, more tailored services, easier access to technology (Steiner, 2003; Cepiku and Meneguzzo, 2004).

We test the hypothesis that integrative public leadership has an impact on the level of performance in networks by using Van Wart's $(2004,2008)$ threefold categorization of leadership behavior in a particular form of intermunicipal networks (unions of municipalities). The purpose is to determine which of the three behavioral categories (peopleoriented; task-oriented; organization oriented) is able to lead to better performing networks.

The paper is structured as follows. Firstly, we summarize the literature on network leadership and network performance. Secondly, we explicate the content of our analysis, unions of municipalities and how this form of intermunicipal collaboration can be considered to be a network. Thirdly, we investigate the extent to which Italian mayors adopt different behaviors in leading local government networks. Lastly, we analyze the correlation between three leadership behavior categories and the level of performance reached as a consequence of the engagement of the behaviors belonging to the three categories by the presidents of municipalities (network leaders).

\section{Network leadership}

Over the last 20 years, there has been an increase in the use of collaborative networks among state and local governments (Silvia, 2011). Van Slyke and Alexander note that the increased use of networks in the public sector presents "a significant departure from leading large, centralized, hierarchically arranged institutions in which the leader guides followers who are employees of their organization" (2006, p. 364). However, whereas it is doubtless that considerable attention has been paid to networks, there has been much less explicit discussion on their leadership (Mandell and Keast, 2009).

In order to avoid confusion between leadership and management, at this stage, a clear distinction between the two concepts ought to be made. Leadership is a purpose-driven or goalinfluencing process based on values, ideals, vision, symbols and emotional exchanges, and it occurs between a leader and a follower, groups of followers or institutions. Management, on the other hand, is task-driven, resulting in stability grounded in rationality, bureaucratic means and the fulfillment of contractual obligations (Bryman, 1992; Antonakis and Day, 2017).

Several leadership theories have developed in an attempt to understand this phenomenon, including formal and informal leadership, the leader as a person, leader behaviors, the effects of a leader, the interaction process between leader(s) and follower(s) and the importance of social cognition as well as context (Antonakis and Day, 2017). However, the literature on network leadership is still nascent and the topic has received far less attention than other instruments of network management.

A consistent stream of research has heavily questioned the view of leadership as a role performed by an individual. More specifically, the principle that forthrightly attributes topdown and formal leadership to single-agency structures and distributed and informal leadership to networks has been strongly contested in the literature (Crosby and Bryson, 2005; Fernandez et al., 2010; Jopling and Crandall, 2006, p. 17). Consequently, leadership should be treated as a shared and dispersed endeavor among members of organizations operating at multiple levels of the hierarchy. Bryson, Crosby and Stone (2006) identify both formal and informal leadership positions in networks emphasizing the absence of a net leadership border between formal and informal leadership in networks.

UhlBien and Marion (2007) define network leadership as leadership of change where traditional leadership, based on organizational frameworks gearing toward efficiency and control has limited applicability to this new context (Streatfield 2001). In fact, three tensions have been identified in the literature as intrinsic to networks: (1) efficiency versus 
inclusiveness; (2) internal versus external legitimacy; (3) flexibility versus stability (Provan and Kenis, 2007, pp. 242-246). In order to fully understand the peculiarities that characterize networks, many scholars endeavored to compare them to single organizations, and several complexities emerged from the comparison, including: different perspectives of the actors involved with the problem, with the desired solution or the best institutional arrangements to solve the issue; varied commitment from the partners to the network goals; culture clash and power issues; loss of autonomy, coordination fatigue and commitment of time and resources; lack of incentives to cooperate and consequent blockades to collective action, potential for reduced accountability by participants and network closeness; few rewards for the role in networks as compared to the role in organizations; absence of important actors; poor deployment of resources; erroneous task integration, among others (Kickert et al., 1997, p. 9; Provan and Milward, 2001; Huxham and Vangen 2000; Mandell and Keast, 2008; Kenis and Provan, 2009, p. 444). Whereas in the agency context, a leader has the responsibility to evaluate performance, punish and reward personnel (Van Slyke and Alexander 2006) and, often times, has the authority to hire and fire, the network leader has none of these powers.

The aforementioned issues make traditional leadership inapplicable to networks and, therefore, the necessity of an integrative public leadership has emerged in the plethora of the academic field. Consequently, few definitions of integrative public leadership were generated. For instance, Crosby and Bryson (2010, p. 211) define it as the ability of "bridging diverse groups and organizations together in semi-permanent ways, and typically across sector boundaries, to remedy complex public problems and achieve the common good." In addition, Bryson et al. define leadership in/of networks or integrative leadership as a process of "aligning initial conditions, processes, structures, governance, contingencies and constraints, outcomes and accountabilities such that public value is created" (Bryson et al., 2006, p. 52).

In the field of network leadership studies, we noticed that two interrelated key issues have occurred: moving toward a shared or distributed leadership concept and focusing on behavior rather than the organizational position. The focus on nonhierarchical, collectivistic leadership is particularly valuable within informal networks (Mumford et al., 2012) and has been steadily increasing with several different theories (Yammarino et al., 2012; Friedrich et al., 2016). In his investigation of local governments, Svara (1994) also promotes a nonhierarchical leadership by describing the new model of facilitative leadership where the leader accomplishes objectives by enhancing the efforts of others. More specifically, in order to empower network members and therefore working effectively together, facilitative network leaders seek to stress collaboration and collective leadership rather than seeking power for themselves.

In regard to the second issue, leadership researchers focused on the behavioral styles that leaders enacted and how they treated followers (Rainey, 2003; Van Wart, 2004, 2005, 2008; Fernandez, 2008). The influential Ohio State University (Stogdill and Coons, 1957; Fleishman, 1953) and University of Michigan (Yoder et al., 1952) studies identified two overarching leadership factors generally referred to as consideration (i.e. supportive, person-oriented leadership) and initiating structure (i.e. directive, task-oriented leadership). Scandinavian scholars such as Ekvall and Arvonen (1991) and Lindell and Rosenquist (1992a; 1992b) added a third category - change-oriented behaviors - and a preliminary test revealed that a threedimensional model offered a better fit with the data (Blake and Mouton, 1964; Ekvall and Arvonen, 1991; Fernandez, 2008). Inconsistent findings suggested that the success of the leader's behavioral style must be contingent on the situation. As a result, leadership theory in the 1960s began to focus on leadership contingencies. Subsequent research focusing on contingency and dyadic theories of leadership, and charismatic and transformational leadership, still keeps a focus on behaviors (Fernandez, 2008; Nahavandi, 2009).

Also the literature on public leadership - which can be defined as "leadership for the common good, for the purpose of creating public value" (Getha-Taylor et al., 2011, p. i84) - has considerably expanded in recent years and has embraced and nurtured research on network 
JPBAFM

32,2

180 leadership (Van Wart, 2013; Ospina, 2016). As a result, the behavioral categories have been enriched, and more recently, models incorporating skills, traits, behaviors and styles along with situational elements have been proposed. Consistent with this approach to leadership research, we adopt a model commonly used in the leadership literature (Van Wart, 2004, 2008), which includes three kinds of behavior: task-oriented, people-oriented and organization-oriented, with the latter two being complementary rather than separate roles.

\section{Network performance}

The links between leadership and performance in networks have not been investigated. In fact, after an early focus on network structure and its impact on network performance (Provan and Milward, 1995; Kickert et al. 1997), the importance of network management and governance for network performance has become a prominent topic in the literature on public networks (Mandell, 2001; Meier and O’Toole, 2001; Klijn et al., 2010; Ysa et al., 2014; Klijn et al., 2016). In addition, the acknowledgment of the "dark side" of networks (O'Toole and Meier, 2004; Provan and Kenis, 2008; Raab and Kenis, 2009: 198; Sørensen and Torfing, 2009) has resulted in an increase of theoretical and empirical interest in the issue of network performance assessment and evaluation in different sectors such as mental health (Provan and Milward, 1995), children's welfare (Graddy and Chen, 2006), education (Meyer and O'Toole, 2001) and environmental-related projects and policies (Van Bueren et al., 2003; Verweij et al., 2013).

Networks face a great variety of challenges mainly due to turf conflict and community accountability (Weiner and Alexander, 1998), which, in turn, see tensions in networks as the main source of clash (Lemaire, 2012). According to McGuire and Agranoff (2011), there are three categories of limitations that lead to tensions in networks: limitations due to working within the bureaucratic state, operational limitations and performance limitations. One of the causes of network performance limitations is "multidimensionality of performance measures" (Lemaire, 2012: 47). Therefore, we endeavor to overcome performance limitations by assessing only dimensions of performance that better represent local government networks and, therefore, make the evaluation of the impact generated by the engagement of different leadership behaviors categories homogeneous and reliable.

Provan and Milward (2001) have identified three levels of performance for assessing networks: the community, the network and the organizational level. Community-level performance can be defined as the extent to which a network satisfies "the needs and expectations of those groups within a community that have both direct and indirect interest in seeing that client needs are adequately met" (Provan and Milward, 2001, p. 417; Verweij et al., 2013). Network-level performance refers to the outcomes of network activity as a specific arrangement that shows to what extent the network is a viable and sustainable form of organization (Provan and Milward, 2001, p. 417; Klijn et al., 2010, p. 197).

Organization-level performance refers to the extent to which the organizations taking part in the network benefit from their involvement (Provan and Milward, 2001). Although there may be several reasons for an organization to join a network, the trade-off between the resources invested and the benefits gained should be positive for all network members. Costs are an important dimension in network settings and are not only related to financial burdens, which an organization incurs in joining the network; costs can also be related to time spent on networking activities that would otherwise be dedicated to internal organizational tasks (Agranoff and McGuire, 1999).

From the analysis of the literature of network performance, emerged the presence of very limited research investigating whether and how network leadership is able to influence network performance. Therefore, we strive to enrich the network performance literature by investigating how leadership behavioral categories, more specifically people-oriented, 
task-oriented and organization-oriented (Van Wart 2004; 2008), are able to lead to better performing networks and to what extent.

In regard to the context analyzed in this research, intermunicipal networks, we considered the most cited performance dimensions highlighted by the intermunicipal cooperation literature as the main goals pursued by the unions of municipalities: cost savings, service quality improvement, financial incentives, better bargaining, more tailored services, easier access to technology (Steiner, 2003; Cepiku and Meneguzzo, 2004).

\section{Intermunicipal networks: unions of municipalities}

The network literature has long ago focused on local government (Svara, 1987; 1990, 1994; 2002) or intermunicipal collaborations, which can assume various forms (Cepiku and Meneguzzo, 2004; Hulst et al., 2009; Feiock and Scholz, 2010; Sorrentino and Simonetta, 2011). Arn and Friederich (1994) and later Steiner (2003) consider intermunicipal collaboration as "the fulfilment of a public municipal task by two or more municipalities jointly or by a third legal entity" (Steiner, 2003, p. 553), whereby the activity serves at least two municipalities simultaneously (Steiner, 2001).

Among these forms, unions of municipalities, the object of our analysis, have been extensively adopted in different countries (Bovaird et al., 2002; OECD, 1997). However, they are much more demanding than other kinds as they consist in the creation of a new administrative coordination authority, endowed with legal and political responsibilities similar to a municipality. Thus, they are much more binding also from a political point of view. In addition, they better display those characteristics that are found to define networks in the literature: they have a NAO type of governance; some network management functions are formally envisaged; they involve multiple organizations with different stakeholders, organizations' cultures and methods of operation; each partner has both common and different missions and, above all, its own interests that must be met (Rhodes, 1997, p. xi; Klijn and Teisman, 1997; Agranoff, 2003, p. 11; Bingham and O'Leary, 2007, p. 10).

In several European countries, local governments have become increasingly autonomous, yet are too small to carry out all the functions delegated by the central government. Therefore, networking and collaboration are expected to contribute to an improvement in the efficiency of local services and in terms of consistency and effectiveness of public policies, by emphasizing functional rather than administrative demarcations. Intermunicipal collaboration principally aims to provide reliable services to citizens who live in small municipalities characterized by limited resources but with the same needs as citizens living in bigger communities. Therefore, there is a great variation in local capacity to meet different types of requirements. This is especially true in small municipalities, which often face depopulation and an aging population. They are increasingly challenged to find renewal strategies and action plans to secure municipal service obligations at a reasonable cost and to find competent staff.

More recently, intermunicipal networks have also become part of cutback packages adopted in countries under fiscal stress, including Italy, where almost $70 \%$ of the municipalities in Italy have less than 5,000 inhabitants and often fail to perform two-thirds of the functions they are liable for (ISTAT, 2018). According to Giacomini and Sancino (2016), intermunicipal cooperation has been implemented in Italy in order to achieve savings in the overall spending review strategy, difficultly pursued by the central government. In particular, Giacomini et al. (2018) examined the effects of intermunicipal cooperation in 280 Italian municipalities, showing that in more than two-thirds of the municipalities analyzed, there were benefits in terms of cost reduction and better public services.

Therefore, it is not surprising that networks are of the utmost importance and strongly preferred to mergers, with $87 \%$ of all Italian local governments taking part in at least one cooperation type (Anci, 2004; Cepiku, 2006; Cepiku et al., 2016). 
JPBAFM 32,2
The unions of municipalities are the most structured form of intermunicipal collaboration in Italy and were introduced in 1990 with the network leader formally elected from one of the mayors of the partner municipalities.

However, although the aim was to provide a tool assisting very small local governments in efficiently carrying out their functions, they registered an initial slow diffusion. In fact, after a decade, there were only 16 unions of municipalities. In 1999, a new law $(n$. 265) removed some obstacles, and consequently, the number of unions reached 206 in 2003, 362 in 2015, 468 in late 2016 and 537 units in 2018 (Ancitel, 2018).

In 2010, intermunicipal cooperation became compulsory for small municipalities (i.e. having less than 5,000 inhabitants or less than 3,000 in case of municipalities belonging to mountain communities). Subsequently, municipalities that adopt the network form in delivering services benefit from fiscal incentives granted by the regions and subventions granted by the central government. These are based on the number of functions associatively conducted rather than on the number of inhabitants.

However, on January 24, 2019, the Constitutional Court through the sentence n. 33 allows local governments to avoid being part of a network if it does not bring any financial benefits or service improvements. This sentence, in fact, lightened the compulsoriness for municipalities to be part of the union if it is not advantageous to them.

It is worth noticing that unions of municipalities are a particularly apt unit of analysis when studying integrative leadership, due to their peculiarities that identify them as networks.

\section{Research aims and methods}

The aim of this research is to investigate the influence of leadership on network performance. The purpose is to better understand if leadership - a neglected network management instrument - is able to influence network performance and to what extent. Six performance dimensions have been considered: cost savings, service quality improvement, financial incentives, better bargaining, more tailored services, easier access to technology.

We test the hypothesis that integrative leadership, identified through three leadership behavior categories (Van Wart, 2004, 2008), is able to influence the level of performance in local government networks in Italy.

The three leadership behavior categories analyzed are people-oriented, task-oriented and organization-oriented behaviors, respectively. They refer to 36 leadership behaviors exhibited in guiding networks and illustrated in Table 1.

The analysis relies upon survey data. In order to receive responses as unbiased as possible, an anonymous Web-based questionnaire was sent out across the country in September 2015 and remained open throughout the year 2017. Prior to retrieving data through the online survey, we decided to pilot test the survey by conducting two pilot face-toface interviews with the double aim to test the comprehension of the questionnaire and the reliability of the answers. The pilot-testing interviews also aimed to erase any doubts that might have arisen from answering the questions. However, the initial responses to the online survey were not representative of the population as the majority being from northern Italy. Therefore, the survey remained opened for an additional timeframe during which only central and southern networks could reply.

Our statistical population was composed of 362 presidents (networks' leaders) who are accountable for the 362 networks (unions of municipalities). The list was generated using contact information gathered from Ancitel, which is a company belonging to ANCI, the National Association of Italian Municipalities. According to David (1938), a sample size equal or superior to 25 suffices to calculate the correlation and our sample is larger than 25. More specifically, we collected 72 completed questionnaires, which represent approximately 


\begin{tabular}{|c|c|c|c|}
\hline People-oriented behaviors & Task-oriented behaviors & Organization-oriented behaviors & d \\
\hline Inspiring enthusiasm for a project & Scheduling the work to be done & $\begin{array}{l}\text { Publicizing the network's goals and } \\
\text { accomplishments }\end{array}$ & \\
\hline Brainstorming & $\begin{array}{l}\text { Letting network members } \\
\text { know what is expected of them }\end{array}$ & $\begin{array}{l}\text { Keeping the network in good } \\
\text { standing with higher authority }\end{array}$ & \\
\hline $\begin{array}{l}\text { Permitting the network members to } \\
\text { use their own judgment in solving } \\
\text { problems }\end{array}$ & $\begin{array}{l}\text { Assigning network members to } \\
\text { particular tasks }\end{array}$ & $\begin{array}{l}\text { Keeping the group in good standing } \\
\text { with stakeholders outside of } \\
\text { network }\end{array}$ & 183 \\
\hline $\begin{array}{l}\text { Permitting the network to set its } \\
\text { own pace }\end{array}$ & $\begin{array}{l}\text { Deciding how tasks will be } \\
\text { performed }\end{array}$ & $\begin{array}{l}\text { Encouraging support from } \\
\text { superiors among network members }\end{array}$ & \\
\hline $\begin{array}{l}\text { Sharing the leadership role with } \\
\text { other network members }\end{array}$ & $\begin{array}{l}\text { Making sure staff roles are } \\
\text { understood by the network } \\
\text { members }\end{array}$ & $\begin{array}{l}\text { Encouraging support from } \\
\text { stakeholders outside of your } \\
\text { network }\end{array}$ & \\
\hline $\begin{array}{l}\text { Putting suggestions made by the } \\
\text { network into operation }\end{array}$ & $\begin{array}{l}\text { Asking that network members } \\
\text { follow standard rules and } \\
\text { regulations }\end{array}$ & Identifying stakeholders & \\
\hline $\begin{array}{l}\text { Treating all network members as } \\
\text { equals }\end{array}$ & $\begin{array}{l}\text { Taking charge when } \\
\text { emergencies arise }\end{array}$ & $\begin{array}{l}\text { Identifying resources (equipment, } \\
\text { supplies, finances, etc.) }\end{array}$ & \\
\hline $\begin{array}{l}\text { Looking out for the personal welfare } \\
\text { of network members }\end{array}$ & $\begin{array}{l}\text { Acting without consulting the } \\
\text { network }\end{array}$ & Changing the network's structure & \\
\hline $\begin{array}{l}\text { Settling conflicts when they occur in } \\
\text { the network }\end{array}$ & $\begin{array}{l}\text { Keeping work moving at a } \\
\text { rapid pace }\end{array}$ & Establishing a shared vision & \\
\hline Maintaining a closely knit network & $\begin{array}{l}\text { Coordinating the work of the } \\
\text { network }\end{array}$ & $\begin{array}{l}\text { Influencing the network's values } \\
\text { and norms }\end{array}$ & \\
\hline $\begin{array}{l}\text { Creating trust among network } \\
\text { members }\end{array}$ & $\begin{array}{l}\text { Establishing agreement } \\
\text { regarding the nature of the } \\
\text { tasks }\end{array}$ & $\begin{array}{l}\text { Establishing member commitment } \\
\text { to the network's mission }\end{array}$ & \\
\hline $\begin{array}{l}\text { Freely sharing information among } \\
\text { network members }\end{array}$ & $\begin{array}{l}\text { Selecting performance } \\
\text { measures }\end{array}$ & & \\
\hline $\begin{array}{l}\text { Using incentives to motivate } \\
\text { network members }\end{array}$ & & & \\
\hline Source(s): Adapted from Van Wart & $(2004,2008)$ & & Leadership bel \\
\hline
\end{tabular}

$19.89 \%$ of the entire statistical population. In the literature, lower respondent rates were considered valid to regard the sample as representative of the population tested. For instance, in Silvia and McGuire's analysis (2010), the respondent rate was evidently lower than ours $(16.77 \%)$. In our analysis, 68 questionnaires were considered valid as a result of 4 out of 72 invalid questionnaires due to the lack of the information given.

Respondents are analyzed and distributed per population and regions as indicated in Table 2.

While the first section of the survey dealt with questions regarding sociodemographic information, the size of the network, its geographical localization and history, the second section posed the following question to the respondents (network leaders): "How often do you engage in the following behaviors within your union of municipalities?" The answer was spread over 36 behaviors (Van Wart, 2008) using a five-point Likert scale: "never," "seldom," "occasionally," "often" and "very often," from one to five.

In the third section of the survey, the presidents of the local government networks were anonymously asked to assess the level of performance of their unions, along six dimensions (cost savings, service quality improvement, financial incentives, better bargaining, more tailored services, easier access to technology), using a five-point Likert scale: "never," "seldom," "occasionally," "often" and "very often," from one to five.

In our analysis we compared the frequency usage of the three categories of leadership behaviors (people-oriented; task-oriented; organization-oriented) exhibited by the leaders (the 


\begin{tabular}{|c|c|c|c|c|c|}
\hline \multirow[t]{2}{*}{$\begin{array}{l}\text { JPBAFM } \\
32,2\end{array}$} & \multirow[b]{2}{*}{ Population group } & \multicolumn{2}{|c|}{$\begin{array}{l}\text { Total Italian unions of } \\
\text { municipalities }\end{array}$} & \multicolumn{2}{|c|}{ Respondent unions } \\
\hline & & $n^{\circ}$ & $\%$ & $n^{\circ}$ & $\%$ \\
\hline \multirow[b]{4}{*}{184} & Less than 1.999 & 16 & $4.42 \%$ & 4 & $5.56 \%$ \\
\hline & Between $2.000-4.999$ & 46 & $12.71 \%$ & 9 & $12.50 \%$ \\
\hline & Between 5.000-9.999 & 80 & $22.10 \%$ & 12 & $16.67 \%$ \\
\hline & Between 10.000-19.999 & 100 & $27.62 \%$ & 20 & $27.78 \%$ \\
\hline \multirow{10}{*}{$\begin{array}{l}\text { Table } 2 \text {. } \\
\text { Respondents to the } \\
\text { survey }\end{array}$} & Between 20.000-59.999 & 93 & $25.69 \%$ & 22 & $30.56 \%$ \\
\hline & More than 60.000 & 27 & $7.46 \%$ & 5 & $6.94 \%$ \\
\hline & Total & 362 & $100 \%$ & 72 & $100.00 \%$ \\
\hline & Regions & & & & \\
\hline & North-East (ER, FVG, TAA, VE) & 59 & $16.30 \%$ & 15 & $20.83 \%$ \\
\hline & North-West (LI, LO, PI, VDA) & 108 & $29.83 \%$ & 21 & $29.17 \%$ \\
\hline & Centre (LA, MA, TO, UM) & 52 & $14.36 \%$ & 9 & $12.50 \%$ \\
\hline & South (AB, BA, CAL, CAM, MOL, PU) & 58 & $16.02 \%$ & 13 & $18.06 \%$ \\
\hline & Islands (SA, SI) & 85 & $23.48 \%$ & 14 & $19.44 \%$ \\
\hline & Total & 362 & $100 \%$ & 72 & $100.00 \%$ \\
\hline
\end{tabular}

presidents of the unions) in leading their networks. Afterward, the leadership behaviors were compared with the level of performance reached in the unions in terms of mean, and the relative correlation coefficient was built and analyzed to investigate the alleged linkage between leadership behaviors and performance in local government networks. We only considered correlation coefficient significant at $1 \%, \alpha=0.01, p<0.001$, and more significantly, there was sufficient evidence to conclude that there was a significant linear relationship between $x$ (leadership behaviors) and $y$ (performance dimensions) as the correlation coefficients were significantly different from 0 .

\section{Findings}

As shown in Table 3, approximately half (47.1\%) of our unions of municipalities responding to the survey are more than 10 years old, while a relatively slight portion $(40.3 \%)$ is composed of 2-4 municipalities. Moreover, the president of the union, the object of our interview, is in the $48.5 \%$ of the cases at the beginning of his/her experience.

Table 4 illustrates how often network leaders engage in each of the 36 leadership behaviors that shape Van Wart's construct $(2004,2008)$. Leaders ranked the extent of use of each behavior on a 1-5 scale, from never (assigning a value of 1 ) to very often (assigning a value of 5).

As shown in Table 4, among the top ten behaviors, five belong to people-oriented behaviors. The leadership behavior used most in leading networks is by far treating all as equals with a mean of 4.00, followed by keeping the network in good standing with higher authority with an average value of 3.85. The third most used behavior in leading local

Table 3.

Features of unions of municipalities
Number of years since the establishment

$>10$ years

8-10 years

6-7 years

4-5 years

1-3 years

$12 \%$

$4 \%$
Number of municipalities per union

Years of presidency

2-4 municipalities

5-7 municipalities

8-10 municipalities

$>10$ municipalities

$\begin{array}{lll}40 \% & \text { 1st year } & 48 \% \\ 31 \% & \text { 2nd year } & 18 \% \\ 21 \% & \text { 3rd year } & 18 \% \\ 8 \% & \text { 4th year } & 4 \% \\ & \text { 5th year } & 12 \%\end{array}$




\begin{tabular}{|c|c|c|c|c|}
\hline Leadership behaviors in networks (P-O-T)* & Type of behavior & Mean usage & Rank & and \\
\hline Treating all as equals & $p$ & 4 & 1 & \\
\hline Keeping in good standing with higher authority & $O$ & 3.85 & 2 & \\
\hline Putting suggestions into operation & $p$ & 3.84 & 3 & \\
\hline Establishing a shared vision & $O$ & 3.78 & 4 & \\
\hline Maintaining a closely knit municipality/network & $p$ & 3.76 & 5 & \\
\hline Looking out for the personal welfare & $p$ & 3.75 & 6 & 185 \\
\hline Taking charge when emergencies arise & $T$ & 3.69 & 7 & \\
\hline Keeping work moving at a rapid pace & $T$ & 3.68 & 8 & \\
\hline Influencing values and norms & $O$ & 3.65 & 9 & \\
\hline Sharing leadership role & $p$ & 3.63 & 10 & \\
\hline Coordinating the work & $T$ & 3.62 & 11 & \\
\hline Scheduling the work to be done & $T$ & 3.61 & 12 & \\
\hline Freely sharing information & $p$ & 3.6 & 13 & \\
\hline Permitting to set its own pace & $p$ & 3.6 & 13 & \\
\hline Deciding how tasks will be performed & $T$ & 3.6 & 13 & \\
\hline Permitting to use own judgment in solving problems & $p$ & 3.57 & 16 & \\
\hline Establishing member commitment to mission & $O$ & 3.57 & 16 & \\
\hline Identifying resources & $O$ & 3.57 & 16 & \\
\hline Establishing agreement regarding the nature of the tasks & $T$ & 3.56 & 19 & \\
\hline Creating trust & $p$ & 3.54 & 20 & \\
\hline Inspiring enthusiasm for a project & $p$ & 3.53 & 21 & \\
\hline Letting all know what is expected of them & $T$ & 3.53 & 21 & \\
\hline Keeping the group in good standing with stakeholders & $O$ & 3.52 & 23 & \\
\hline Using incentives to motivate & $p$ & 3.51 & 24 & \\
\hline Selecting performance measures & $T$ & 3.51 & 24 & \\
\hline Publicizing goals and accomplishments & $O$ & 3.51 & 24 & \\
\hline Brainstorming & $p$ & 3.44 & 27 & \\
\hline Asking to follow standard rules and regulations & $T$ & 3.43 & 28 & \\
\hline Making sure individual roles are understood & $T$ & 3.42 & 29 & \\
\hline Assigning to particular tasks & $\mathrm{T}$ & 3.38 & 30 & \\
\hline Encouraging support from stakeholders & $O$ & 3.34 & 31 & \\
\hline Settling conflicts when they occur & $p$ & 3.33 & 32 & \\
\hline Encouraging support from superiors & $O$ & 3.31 & 33 & \\
\hline Identifying stakeholders & $O$ & 3.26 & 34 & \\
\hline Changing the network's structure & $O$ & 3.15 & 35 & $\begin{array}{l}1 \text { able } 4 . \\
\text { Inteorative leadersin }\end{array}$ \\
\hline Acting without consulting & $T$ & 2.87 & 36 & $\begin{array}{l}\text { Integrative leadership } \\
\text { behaviors (ranked by }\end{array}$ \\
\hline \multicolumn{5}{|c|}{ Note(s): * People-oriented behaviors; $T=$ Task-oriented behaviors; $O=$ Organization-oriented behaviors } \\
\hline
\end{tabular}

government networks is putting suggestions into operations, which might be useful to find agreed solutions to problems and initiatives. The fourth behavior is establishing a shared vision, necessary in order to preserve identity and motivation. The existence of unlike and common missions between members, different cultures and method of operation can germinate conflicts and slowdowns.

At the bottom of the rank we find acting without consulting the network and changing the network's structure, and the reason could be that consultation is crucial for the network to keep functioning and that the network's mission and identity ought to be jointly shared and pursued among the network's members.

At this point of the research we can compare the mean values aggregated for each behavior category (Table 5).

The mean usage for all 36 behaviors used in networks is 3.54 (Table 4), which shows that in the aggregate, network leaders exhibit these behaviors in networks slightly less than "often" but more than "occasionally." 
JPBAFM

32,2

186

The highest mean registered in integrative leadership belongs to people-oriented behaviors with a mean value of 3.62, and it demonstrates their dominance in leading networks in comparison with both organization-oriented (3.50) and task-oriented behaviors (3.49), with the latter more related to monitoring and assessing work, operations planning, clarifying roles and objectives, informing, delegating, problem-solving and managing innovation and creativity (Van Wart, 2008: 192). Organization-oriented behaviors registered a mean value of 3.50 (almost the same as the mean value registered by the task-oriented leadership behaviors category, 3.49), where in the top five leadership behaviors, five are organization-oriented and none are task-oriented.

In order to visually compare the differences in usage in each of the 36 leadership behaviors engaged by 68 respondents to the survey (presidents of the unions of municipalities), Figure 1 shows the ranking expressed in terms of length of the horizontal bars, which are displayed in three different colors according to the three leadership behaviors categories. The black line shows people-oriented behaviors, while the gray and the light gray lines show organization-oriented and task-oriented leadership behaviors, respectively.

The shorter is the bar, the higher the ranking for that specific behavior (from 1 to 36). The sequence of bars shows general propensity and, more in detail, how differently a specific leadership behavior is averagely engaged by the presidents of local government networks, allowing a more visual and direct comparison of the usage of the three leadership behaviors categories.

As shown in Figure 1, in the top three behaviors, two are people-oriented and ten of the 13 people-oriented behaviors are ranked in the top 17. Van Wart's people-oriented behaviors involve "consulting, planning and organizing personnel, developing staff, motivating, building and managing teams, managing conflict, and managing personnel change."

Regarding the category of task-oriented behaviors, almost half of the 12 task-oriented behaviors placed in the top 15 , where taking charge when emergencies arise is the most used leadership behavior, followed by keeping work moving at a rapid pace and coordinating the work, which is an essential part of managing and coordinating multiple partners within the networks. Letting all know what is expected of them is positioned in the middle of the ranking due to the prevalence of informal rules. At the bottom of the ranking of the leadership behaviors adopted by local government networks' leaders, there is acting without consulting, confirming the relevance of consultation in leading networks.

In the category of organization-oriented behaviors, only three of the 11 organizationoriented behaviors placed in the top 15 and with almost two-thirds of the behaviors placed at the bottom of the ranking. Within this category, keeping in good standing with higher authority and establishing a shared vision ranked in the top five leadership behaviors exhibited by the presidents of the unions of municipalities. More specifically, they ranked two and four because they are considered necessary in order to preserve identity and motivation. In addition, influencing values and norms and establishing member commitment to mission ranked in the top 16, and this may be motivated by a higher heterogeneity of aims and organizational cultures inside a local government network.

In the last part of our research we analyzed the link between leadership behaviors and performance reached in networks. More specifically, in order to test the hypothesis according

Table 5 .

Network value

Leadership behaviors 
Leadership and performance

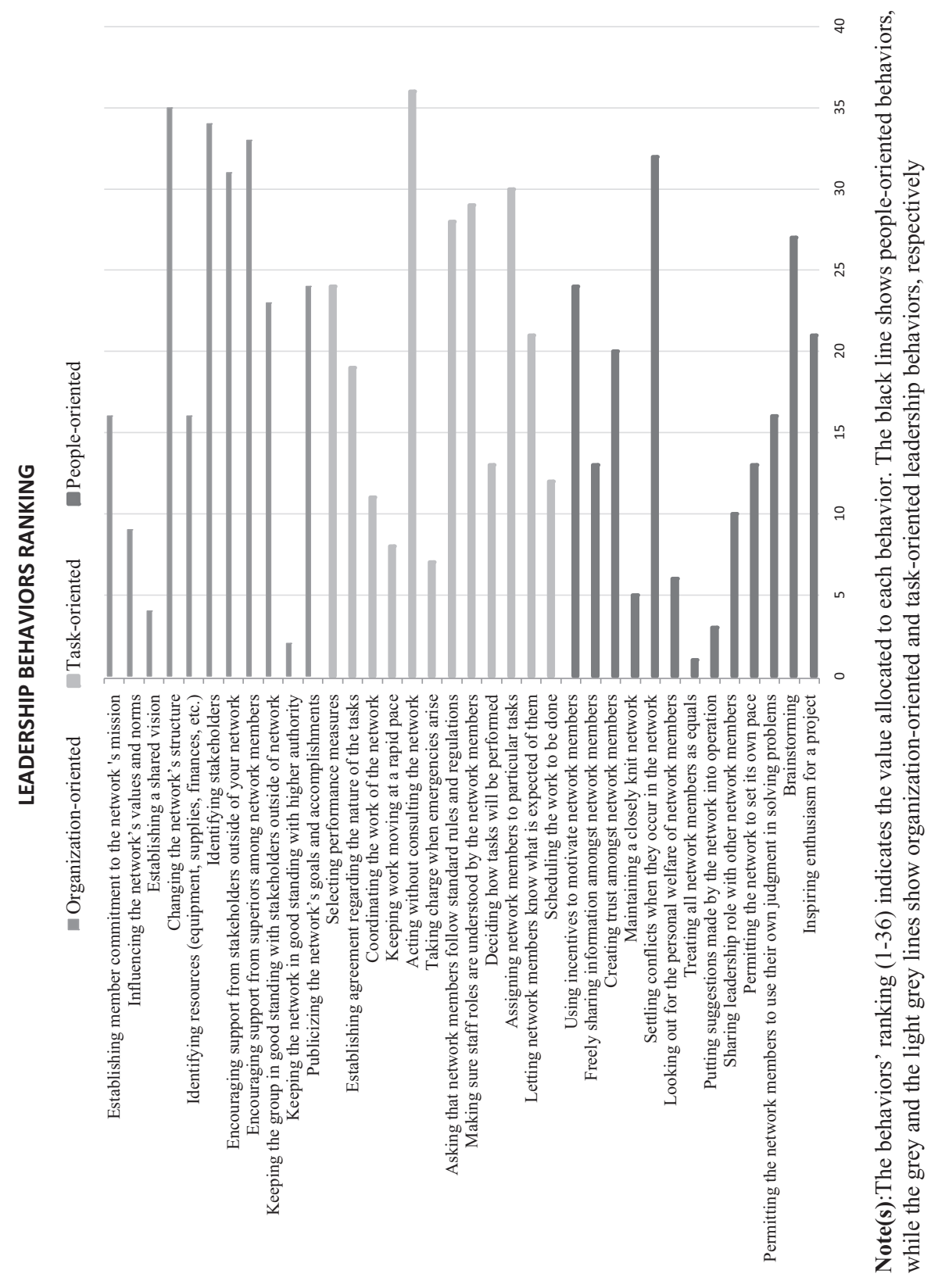

187

Figure 1.

Comparison of leadership behaviors' rankings in local government networks 
JPBAFM

32,2

188

to which integrative public leadership has an impact on the level of performance in local government networks, we compared the leadership behaviors engaged in every single union of municipalities (explanatory variables) with six performance dimensions (response variables): cost savings, service quality improvement, financial incentives, better bargaining, more tailored services, easier access to technology.

In addition, to guarantee reliability of the responses, the performance dimensions analyzed were anonymously assessed by the presidents of the unions through a five-point Likert Scale. Afterward, we built the correlation coefficient between the two variables (Table 6).

Results show that integrative leadership behaviors have a positive impact on the performance level reached in local government networks. More specifically, as Table 6 shows, all three categories of leadership behavior (people-task-organizational-oriented) are positively correlated to the average level of performances measured. All correlation coefficients are statistically significant at $1 \%, p<0.001$.

The more consistent the leadership is in terms of mean value, the higher is the average level of performance reached through the engagement of that specific leadership behavior category. More specifically, in the 68 unions of municipalities analyzed, leaders implementing one of the different organization-oriented behaviors performed most effectively, registering the highest correlation coefficient at 0.58. People- and task-oriented behaviors show a marginally lower correlation with performances accomplished, at 0.49 and 0.47 , respectively.

\section{Discussion}

The aim of this study was to investigate if integrative leadership is able to affect network performance in one of the intermunicipal union collaboration types: unions of municipalities.

More specifically, we examined Van Wart's $(2004$; 2008) threefold categorization (peopleoriented, task-oriented and organization-oriented) of leadership behaviors engaged by the presidents of the Italian unions of municipalities (public networks' leaders) and analyzed their impact on six performance dimensions: cost savings, service quality improvement, financial incentives, better bargaining, more tailored services, easier access to technology (Steiner, 2003; Cepiku and Meneguzzo, 2004).

We also compared the frequency usage of each leadership behavior category expressed in terms of mean with the level of performance achieved in the unions of municipalities (object of our analysis) and the relative correlation coefficient was built to show the existence, and the extent, of linear dependence between the independent or explanatory variables (leadership behaviors) and the dependent or response variable (network performance).

Surprisingly, findings showed that the high frequency in the usage of a specific category of leadership behavior does not always lead to high performance in networks.

More specifically, people-oriented behaviors were, on average, the most frequently integrative leadership category engaged by the local government leaders. In particular, two specific behaviors (treating all as equals and putting suggestions into operations) placed in the top three behaviors in the ranking.

The organization-oriented behavior category is the second most frequently used among unions of municipalities. In particular, keeping the network in good standing with higher

Table 6.

Correlation between leadership behaviors and performance within unions of municipalities
Leadership behaviors - networks performance

Correlation coefficient

People-oriented

Task-oriented

Organization-oriented

$0.49 * * *$

$0.47 * * *$

$0.58 * * *$

Note(s): Asterisks indicate the significance of the coefficients at $1 \%(* * *)$ when $p<0.001$ 
authority ranked second in the top five integrative leadership behaviors with an average value of 3.85. This can be explained by the fact that the latter is an important integrative behavior because it motivates commitment and support from network participants and stakeholders (Silvia and McGuire, 2010) and strengthens the legitimacy of the network (Milward and Provan, 2006). As Table 6 shows, organization-oriented behaviors registered the highest correlation with network performance even though it did not register the highest frequency adoption (Table 5).

Lastly, the task-oriented behavior category, which includes those actions related to "monitoring and assessing work, operations planning, clarifying roles and objectives, informing, delegating, problem solving, and managing innovation and creativity" (Van Wart, 2008, p. 192), registered the lowest value of both the average frequency usage of leadership behaviors in networks (Table 5) and correlation with network performance (Table 6). Only two leadership behaviors (taking charge when emergencies arise and keeping work moving at a rapid pace) ranked in the top ten most used leadership behaviors in leading local government networks expressed in terms of average adoption.

The analysis of linear dependency between leadership behaviors and performance allowed us to conclude that leadership can be considered as a performance determinant in leading local government networks. Therefore, we can accept the initial hypothesis according to which integrative public leadership has an impact on the level of performance in networks due to the fact that all three leadership behaviors categories analyzed are positively correlated to the performance reached within the networks. More specifically, from the analysis of the alleged link between leadership behaviors and performance reached in unions of municipalities, organization-oriented behaviors resulted as the most influential behaviors in terms of performance, followed by people-oriented and task-oriented (see Table 6).

It is worth noticing that even though leadership behaviors belonging to the organization-oriented category registered the highest correlation coefficient with the performance reached, they are an average and not the most used leadership behaviors by leaders of local government networks compared to both people-oriented and task-oriented categories. Among these organization-oriented leadership behaviors we have: identifying stakeholders, changing the network's structure, establishing a shared vision, influencing the network's values and norms, establishing member commitment to the network's mission. This inverse relation between performance and frequency usage may be due to the fact that organization-oriented behaviors are mainly related to initial activities implemented by the leader at the establishment of the network. Once they have been converted into actions, these leadership behaviors may lose relevance for the functioning of the network throughout the years, while other leadership behaviors such as people-oriented and task-oriented may be considered more relevant for the functioning of the network.

\section{Conclusions}

Overall, our findings confirm the hypothesis according to which leadership is able to generate an impact on performance in networks. More specifically, all three leadership categories taken into consideration in our analysis, people-oriented, task-oriented and organization-oriented (Van Wart, 2004;2008), have demonstrated to have an impact on local government networks (unions of municipalities), which is our context of analysis. The empirical analysis of the extent of the impact of leadership behaviors on performance can be considered an enhancement in the network performance literature. In fact, our results show that all organization-oriented behaviors resulted as the most influential behaviors in terms of performance, followed by people-oriented and task-oriented.

However, there is no connection between the frequency in the usage of specific leadership behaviors and their impact on the performance of the network. Findings show that the high 
JPBAFM 32,2

frequency in the usage of a specific category of leadership behavior does not always lead to high performance in networks. More specifically, leadership behaviors belonging to the organization-oriented category registered the highest correlation coefficient with the network performance even though they are not the most used leadership behaviors by networks' leaders compared to both people-oriented (the most frequently used) and task-oriented categories. Therefore, this paper should influence practitioners' activities, especially in regard to the engaging in specific leadership behaviors that lead to better performing networks.

However, this study presents its own limitations. Among all, the main drawback is the self-declaration of the performance level achieved by the network leaders. However, the entirely voluntary participation in the interview and the anonymity granted to the respondents gave high expectations of validity, reliability and accuracy of responses. In addition, the study does not include some independent control variables such as age and gender of the network leader (president of the union of municipalities) that might influence the engagement of specific types of leadership behaviors and, therefore, impact the network performance. This new prospective could be included in future additional research. In addition, future research could involve multiple case studies, which could deepen the investigation and therefore overcome the limitations of the survey and which is not often able to perceive and detect the nuances of phenomenon explored.

Future research could address other forms of intermunicipal collaborations that exist in Italy such as memorandums of understandings; conventions; program agreements; joint implementation of functions; consortia and mountain communities, and it could also consider other national contexts such as the French intercommunalite, the Spanish mancomunidad, as well as similar aggregations in Germany and Switzerland.

\section{References}

Agranoff, R. and McGuire, M. (1999), "Managing in network settings", The Review of Policy Research, Vol. 16 No. 1, pp. 18-41.

Agranoff, R. (2003), Leveraging Networks: A Guide for Public Managers Working across Organizations, IBM Endowment for The Business of Government, Washington, D.C., Virginia.

Alexander, J.A., Comfort, M.E., Weiner, B.J. and Bogue, R. (2001), "Leadership in collaborative community health partnerships”, Nonprofit Management and Leadership, Vol. 12, pp. 159-175.

Anci (2004), Associazionismo e cooperazione nell'unione, Cooperazione dei Comuni di minore dimensione demografica come garanzia per lo sviluppo locale nazionale/europeo, ANCI-AMF-CLAIR, Paris.

Ancitel (2018), "Unioni dei Comuni”, available at: http://www.comuniverso.it/index.cfm?Associated_ Municipalities\&menu=314 (accessed 15 January 2018).

Antonakis, J. and Day, D.V. (2017), The Nature of Leadership, Sage Publications, Thousand Oaks, CA.

Arn, D. and Friederich, U. (1994), Gemeindeverbindungen in der Agglomeration, Nationales Forschungsprogramm 'Stadt und Verkehr'.

Avery, G.C. (2004), Understanding Leadership: Paradigms and Cases, Sage Publications, Thousand Oaks, CA.

Baker, E., Kan, M. and Teo, S.T. (2011), "Developing a collaborative network organization: leadership challenges at multiple levels", Journal of Organizational Change Management, Vol. 24 No. 6, pp. 853-875.

Bingham, L.B. and O'Leadry, R. (2007), "A manager's guide to resolving conflicts in collaborative networks", IBM Business of Government, Networks, Collaboration and Partnerships Series.

Blake, R. and Mouton, J. (1964), The Managerial Grid: The Key to Leadership Excellence, Gulf Publishing, Houston.

Bovaird, T., Loffler, E. and Parrado Diez, S. (2002), Developing Local Governance Networks in Europe, Nomos Publishers, Baden-Baden, Germany. 
Bryman, A. (1992), Charisma and Leadership in Organizations, Sage, London.

Bryson, J., Crosby, B. and Stone, M.M. (2006), "The design and implementation of cross sector collaborations: propositions from the literature", Public Administration Review, Vol. 66 No. s1, pp. 44-55.

Cepiku, D. and Meneguzzo, M. (2004), "Public sector networks: what can we learn from different approaches?”, in Osborne, S.P., Jenei, G., McLaughlin, K. and Mike, K. (Eds), Challenges of Public Management Reforms: Theoretical Perspectives and Recommendations, Budapest University.

Cepiku, D., Mussari, R. and Giordano, F. (2016), "Local governments managing austerity: approaches, determinants and impact”, Public Administration, Vol. 94 No.1, pp. 223-243.

Cepiku, D. (2006), "Kommunale Kooperationen und kommunale Fusionen. Ein internationaler Vergleich von Reformen territorialer Governance-Strukturen”, in Kleinfeld, R., Plamper, H. and Huber, A. (Eds), Regional Governance: Erfolg durch neue Formen überörtlicher Zusammenarbeit, Vandenhoeck \& Ruprecht Unipress, Göttingen.

Chrislip, D.D. (2002), The Collaborative Leadership Fieldbook: A Guide to Citizens and Civic Leaders, Jossey-Bass, San Francisco.

Connelly, D.R. (2007), "Leadership in the collaborative interorganizational domain", International Journal of Public Administration, Vol. 30, pp. 1231-1262.

Crosby, B. and Bryson, J. (2005), Leadership for the Common Good: Tackling Public Problems in a Shared-Power World, Jossey-Bass, San Francisco, CA.

Crosby, B. and Bryson, J. (2010), "Special issue on public integrative leadership: multiple turns of a kaleidoscope", The Leadership Quarterly, Vol. 21 No. 2, pp. 211-230.

Crosby, B. and Bryson, J. (2017), "Why leadership of public leadership research matters: and what to do about it", Public Management Review, Vol. 20 No. 9, pp. 1265-1286.

David, F. (1938), Tables for the Correlation Coefficient, Cambridge University Press, Cambridge.

Ekvall, G. and Arvonen, J. (1991), "Change-centered leadership: an extension of the two-dimensional model", Scandinavian Journal of Management, Vol. 7 No. 1, pp. 17-26.

Feiock, R.C. and Scholz, J.T. (2010), "Self-organizing governance of institutional collective actions dilemmas: an overview", in Feiock, R.C. and Scholz, J.T. (Eds), Self-Organizing Federalism: Collaborative Mechanisms to Mitigate Institutional Collective Action, Cambridge University Press, Cambridge, pp. 3-32.

Fernandez, S., Cho, Y.J. and Perry, J.L. (2010), "Exploring the link between integrated leadership and public sector performance”, The Leadership Quarterly, Vol. 21 No. 2, pp. 308-323.

Fernandez, S. (2008), "Examining the effects of leadership behavior on employee perceptions of performance and job satisfaction”, Public Performance and Management Review, Vol. 32 No. 2, pp. 175-205.

Fleishman, E.A. (1953), "The description of supervisory behavior", Journal of Applied Psychology, Vol. 37 No. 1, pp. 1-6.

Friedrich, T.L., Griffith, J.A. and Mumford, M.D. (2016), "Collective leadership behaviors: evaluating the leader, team network and problem situation characteristics that influence their use", The Leadership Quarterly, Vol. 27 No. 2, pp. 312-333.

Getha-Taylor, H., Holmes, M.H., Jacobson, W.S., Morse, R.S. and Sowa, J.E. (2011), "Focusing the public leadership lens: research propositions and questions in the Minnowbrook tradition”, Journal of Public Administration Research and Theory, Vol. 21 suppl_1, pp. i83-i97.

Giacomini, D. and Sancino, A. (2016), "Inter-municipal Co-operation in Italy: a reform without reformers?", Regions Magazine, Vol. 303 No. 1, pp. 19-21.

Giacomini, D., Sancino, A. and Simonetto, A. (2018), "The introduction of mandatory inter-municipal cooperation in small municipalities: preliminary lessons from Italy", International Journal of Public Sector Management, Vol. 31 No. 3, pp. 331-346. 
JPBAFM 32,2

Graddy, E.A. and Chen, B. (2006), "Influences on the size and scope of networks for social service delivery", Journal of Public Administration Research and Theory, Vol. 16 No. 4, pp. 533-552.

Hulst, R., Van Montfort, A., Haveri, A., Airaksinen, J. and Kelly, J. (2009), "Institutional shifts in intermunicipal service delivery”, Public Organization Review, Vol. 93 No. 3, pp. 263-285.

Huxham, C. and Vangen, S. (2000), "Leadership in the shaping and implementation of collaboration agendas: how things happen in a (not quite) joined up world", Academy of Management Journal, Vol. 43 No. 6, pp. 1159-1175.

ISTAT (2018), "Comuni per classi demografiche", available at: http://www.comuniverso.it/index.cfm? Comuni_per_classi_demografiche\&menu $=13$ (accessed 15 January 2018).

Jopling, M. and Crandall, D.P. (2006), "Leadership in networks: patterns and practices", Learning Networks Research Legacy, National College for School Leadership.

Kenis, P. and Provan, K.G. (2009), "Towards an exogenous theory of public network performance", Public Administration, Vol. 87 No. 3, pp. 440-456.

Kickert, W.J.M., Klijn, E.H. and Koppenjan, J.F.M. (1997), Managing Complex Networks, Strategies for the Public Sector, SAGE, London.

Kiefer, J.J. and Montjoy, R.S. (2006), "Incrementalism before the storm: network performance for the evacuation of new orleans", Public Administration Review, Vol. 66(s1), pp. 122-130.

Klijn, E.H. and Teisman, G.R. (1997), "Strategies and games in networks", in Kickert, W.J.M., Klijn, E.H. and Koppenjan, J.F.M. (Eds), Managing Complex Networks, Strategies for the Public Sector, Sage, London, pp. 98-118.

Klijn, E.H., Steijn, A.J. and Edelenbos, J. (2010), "The impact of network management strategies on the outcomes in governance networks", Public Administration, Vol. 88 No. 4, pp. 1063-1082.

Klijn, E.H., Sierra, V., Ysa, T., Berman, E., Edelenbos, J. and Chen, D.Y. (2016), "The influence of trust on network performance in Taiwan, Spain and The Netherlands: a cross-country comparison”, International Public Management Journal, Vol. 19 No. 1, pp. 111-139.

Lemaire, R. (2012), "The functions of the network executive: a case study of network management, leadership and governance", $\mathrm{PhD}$ thesis, University of Arizona.

Lemaire, R.H. and Provan, K.G. (2010), November, "The functions of network executives: multifaceted leadership in a publicly funded child and youth health network", in 32nd Annual APPAM Research Conference: Making Fair and Effective Policy in Difficult Times, Boston, MA, USA, pp. 4-6.

Lindell, M. and Rosenqvist, G. (1992a), "Is there a third management style?", The Finnish Journal of Business Economics, Vol. 3, pp. 171-198.

Lindell, M. and Rosenqvist, G. (1992b), "Management behavior dimensions and development orientation", The Leadership Quarterly, No. 4, pp. 355-377.

Lipnack, J. and Stamps, J. (1994), The Age of the Network: Organizing Principles for the 21st Century, Omneo, Essex.

Mandell, M.P. and Keast, R. (2008), "Evaluating the effectiveness of interorganizational relations through network”, Public Management Review, Vol. 10 No. 6, pp. 715-731.

Mandell, M.P. and Keast, R. (2009), "A new look at leadership in collaborative networks: process catalysts”, in Jeffrey, A., R., Leisink, P., Anthony, E. and Middlebrooks, A.E. (Eds), Public Sector Leadership: International Challenges and Perspectives, Edward Elgar Publishing, Cheltenham, Glos, GL, and Mass, pp. 163-178.

Mandell, M.P. (2001), Getting Results through Collaboration: Networks and Network Structures for Public Policy and Management, 1st ed., Quorum Books, Westport, CT.

McGuire, M. and Agranoff, A. (2011), "The limitations of public management networks", Public Administration, Vol. 89 No. 2, pp. 265-284. 
Meier, K.J. and O’Toole, L.J. Jr (2001), "Managerial strategies and behavior in networks: a model with evidence from US public education", Journal of Public Administration Research and Theory, Vol. 11 No. 3, pp. 271-294.

Milward, H.B. and Provan, K.G. (2006), A Manager's Guide to Choosing and Using Collaborative Networks, IBM Center for the Business of Government, Washington, DC ,Vol. 8.

Mumford, M.D., Friedrich, T.L., Vessey, W.B. and Ruark, G.A. (2012), "Collective leadership: thinking about issues vis-à-vis others", Industrial and Organizational Psychology, Vol. 5 No. 4, pp. 408-411.

Nahavandi, A. (2009), The Art and Science of Leadership, 5th ed., Pearson Education, Upper Saddle River, NJ.

OECD (1997), Managing across Levels of Government, OECD, Paris.

Ospina, S.M. (2016), "Collective leadership and context in public administration: bridging public leadership research and leadership studies", Public Administration Review, Vol. 77 No. 2, pp. 275-287.

O’Toole, L.J. Jr and Meier, K.J. (2004), "Desperately seeking Selznick: cooptation and the dark side of public management in networks", Public Administration Review, Vol. 64 No.6, pp. 681-693.

O’Toole, L.J. Jr (1997), "Treating networks seriously: practical and research-based agendas in public administration", Public Administration Review, Vol. 57 No.1, pp. 45-52.

Provan, K. and Kenis, P. (2007), "Modes of network governance: structure, management and Effectiveness", Journal of Public Administration Research and Theory, Vol. 18 No. 2, pp. 229-252.

Provan, K.G. and Kenis, P. (2008), "Modes of network governance: structure, management and effectiveness”, Journal of Public Administration Research and Theory, Vol. 18 No. 2, pp. 229-252.

Provan, K.G. and Milward, H.B. (1995), "A preliminary theory of interorganizational effectiveness: a comparative study of four community mental health systems", Administrative Science Quarterly, Vol. 40 No. 1, pp. 1-33.

Provan, K.G. and Milward, H.B. (2001), "Do networks really work? A framework for evaluating public sector organizational networks", Public Administration Review, Vol. 61 No. 4, pp. 414-423.

Raab, J. and Kenis, P. (2009), "Heading toward a society of networks: empirical developments and theoretical challenges", Journal of Management Inquiry, Vol. 18 No. 3, pp. 198-210.

Rainey, H.G. (2003), Understanding and Managing Public Organizations, 3rd ed., Jossey-Bass, San Francisco.

Rhodes, R. (1997), Understanding Governance: Policy Networks, Governance, Reflexivity and Accountability, Open University Press, Buckingham.

Silvia, C. (2011), "Collaborative governance concepts for successful network leadership”, State and Local Government Review, Vol. 43 No. 1, pp. 66-71.

Silva, C. and McGuire, M. (2010), "Leading public sector networks: an empirical examination of integrative leadership behaviors", The Leadership Quarterly, Vol. 21 No. 2, pp. 264-277.

Sørensen, E. and Torfing, J. (2009), "Making governance networks effective and democratic through metagovernance", Public Administration, Vol. 87 No. 2, pp. 234-258.

Sorrentino, M. and Simonetta, M. (2011), "Incentivising inter-municipal collaboration: the Lombard experience", Journal of Management and Governance, Vol. 17 No. 4, pp. 887-906.

Steiner, R. (2001), "Intermunicipal cooperation and municipal mergers in Switzerland: local authorities in search of an optimum organization size for the fulfillment of tasks", Institute for Organization and Personnel Management, Work Report No. 48.

Steiner, R. (2003), "The causes, spread and effects of inter-municipal cooperation and municipal mergers in Switzerland”, Public Management Review, Vol. 5 No. 4, pp. 551-571.

Stiver, D.C. (2017), "Catalyzing collective action: a grounded theory of network leadership", PhD thesis, Eastern University. 
JPBAFM 32,2
Stogdill, R.M. and Coons, A.E. (1957), Leader Behavior: Its Description and Measurement, Bureau of Business Research, Ohio State University, Oxford.

Streatfield, P.J. (2001), The Paradox of Control in Organizations, Routledge, London.

Sun, P.Y. and Anderson, M.H. (2012), "Civic capacity: building on transformational leadership to explain successful integrative public leadership", The Leadership Quarterly, Vol. 23 No. 3, pp. 309-323.

Svara, J.H. (1987), "Mayoral leadership in council-manager cities: preconditions versus preconceptions", The Journal of Politics, Vol. 49 No. 1, pp. 207-227.

Svara, J.H. (1990), Official Leadership in the City: Patterns of Conflict and Cooperation, Oxford University Press on Demand, Oxford.

Svara, J.H. (1994), Facilitative Leadership in Local Government: Lessons from Successful Mayors and Chairpersons, Jossey-Bass, San Francisco, CA.

Svara, J.H. (2002), "The roles of the city council and implications for the structure of city government", National Civic Review, Vol. 91 No. 1, pp. 5-23.

UhlBien, M. and Marion, R. (2007), Complexity Leadership: Part 1: Conceptual Foundations, IAP, Charlotte, NC.

Umble, K., Steffen, D., Porter, J., Miller, D., Hummer-McLaughlin, K., Lowman, A. and Zelt, S. (2005), "The National Public Health Leadership Institute: evaluation of a team-based approach to developing collaborative public health leaders", American Journal of Public Health, Vol. 95, No. 4, pp. 641-644.

Van Bueren, E.M., Klijn, E.H. and Koppenjan, J.F.M. (2003), "Dealing with wicked problems in networks: analyzing an environmental debate from a network perspective", Journal of Public Administration Research and Theory, Vol. 13 No. 2, pp. 193-212.

Van Slyke, D.M. and Alexander, R.W. (2006), "Public service leadership: opportunities for clarity and coherence", The American Review of Public Administration, Vol. 36 No. 4, pp. 362-374.

Van Wart, M. (2004), "A comprehensive model for organizational leadership: the leadership action cycle", International Journal of Organization Theory and Behavior, Vol. 7 No. 2, pp. 173-208.

Van Wart, M. (2005), Dynamics of Leadership in Public Service: Theory and Practice, M.E. Sharpe, Armonk, New York.

Van Wart, M. (2008), Leadership in Public Organizations: An Introduction, M.E. Sharpe, Armonk, New York.

Van Wart, M. (2013), Changing Public Sector Values, Routledge, London.

Vangen, S. and Huxham, C. (2003), "Enacting leadership for collaborative advantage: dilemmas of ideology and pragmatism in the activities of partnership managers", British Journal of Management, Vol. 14, pp. S61-S76.

Verweij, S., Klijn, E.H., Edelenbos, J. and Van Buuren, A. (2013), "What makes governance networks work? A fuzzy set qualitative comparative analysis of 14 Dutch spatial planning projects", Public Administration, Vol. 91 No. 4, pp. 1035-1055.

Weiner, Bryan J. and Jeffrey Alexander, A. (1998), "The Challenges of governing public private community health partnerships", Health Care Management Review, Vol. 23 No. 2, pp. 39-55.

Yammarino, F.J., Salas, E., Serban, A., Shirreffs, K. and Shuffler, M.L. (2012), "Collectivistic leadership approaches: putting the 'we' in leadership science and practice", Industrial and Organizational Psychology, Vol. 5, pp. 382-402.

Yoder, D., Katz, D., Maccoby, N., Gurin, G. and Floor, L.G. (1952), "Productivity, supervision and morale among railroad workers", Journal of the American Statistical Association, Vol. 47 No. 259, pp. 573-574.

Ysa, T., Sierra, V. and Esteve, M. (2014), "Determinants of network outcomes: the impact of management strategies", Public Administration, Vol. 92 No. 3, pp. 636-655. 


\section{Further reading}

Agranoff, R. and McGuire, M. (2001), "Big questions in public network management research", Journal of Public Administration Research and Theory, Vol. 11 No. 3, pp. 295-326.

Agranoff, R. and McGuire, M. (2003), Collaborative Public Management: New Strategies for Local Governments, Georgetown University Press, Washington DC.

Agranoff, R. (2006), "Inside collaborative networks: ten lessons for public managers", Public Administration Review", Vol. 66, pp. 56-65.

Agranoff, R. (2007), Managing within Networks: Adding Value to Public Organizations, Georgetown University Press, Washington, DC.

Ayman, R. and Adams, S. (2018), "Contingencies, context, situation and leadership", in Antonakis, J. and Day, D.V. (Eds), The Nature of Leadership, Sage, pp. 218-255.

Bleicher, J. (2014), The Hermeneutic Imagination (RLE Social Theory): Outline of a Positive Critique of Scientism and Sociology, Routledge, London.

Cepiku, D., Mussari, R., Poggesi, S. and Reichard, C. (2014), "Governance of networks: challenges and future issues from a public management perspective", Editorial of the special issue, Journal of Management \& Governance, Vol. 18 No. 1, pp. 1-7.

Cepiku, D. (2014), "Network performance: towards a dynamic multidimensional model", in Robyn Keast, R., Mandell, M.P. and Agranoff, R. (Eds), Network Theory in the Public Sector: Building New Theoretical Frameworks, Chapter 11, Taylor \& Francis/Routledge, New York.

Dilthey, W. (1976), Selected Writings, Cambridge University Press, Cambridge.

Friedrich, T.L., Byrne, C.L. and Mumford, M.D. (2009a), "Methodological and theoretical considerations in survey research", The Leadership Quarterly, Vol. 20 No. 2, pp. 57-60.

Friedrich, T.L., Vessey, W.B., Schuelke, M.J., Ruark, G.A. and Mumford, M.D. (2009b), “A framework for understanding collective leadership: the selective utilization of leader and team expertise within networks", The Leadership Quarterly, Vol. 20 No. 6, pp. 933-958.

Fuller, B.W. and Vu, K.M. (2011), "Exploring the dynamics of policy interaction: feedback among and impacts from multiple, concurrently applied policy approaches for promoting collaboration", Journal of Policy Analysis and Management, Vol. 30 No. 2, pp. 359-380.

Guo, X. and Kapucu, N. (2015), "Network performance assessment for collaborative disaster response", Disaster Prevention and Management, Vol. 24 No. 2, pp. 201-220.

Heranz, J. (2010), "Network performance and coordination", Public Performance and Management Review, Vol. 33 No. 3, pp. 311-341.

Hsieh, J.Y. and Liou, K.T. (2018), "Collaborative leadership and organizational performance: assessing the structural relation in a public service agency", Review of Public Personnel Administration, Vol. 38 No. 1, pp. 83-109.

Jasny, L. (2012), "Baseline models for two-mode social network data", Policy Studies Journal, Vol. 40 No. 3, pp. 458-491.

Kapucu, N. and Demiroz, F. (2011), "Measuring performance for collaborative public management using network analysis methods and tools", Public Performance and Management Review, Vol. 34 No. 4, pp. 549-579.

Katz, R.L. (1955), "Skills of an effective administrator", Harvard Business Review, Vol. 33 No. 1, pp. 33-42.

Lee, S. and Fleming, R.T. (2015), "Collaborative disaster management in local governments: perception, performance and challenges", International Journal of Emergency Management, Vol. 11 No. 4, pp. 343-355.

Lee, I., Feiock, R.C. and Lee, Y. (2012), "Competitors and cooperators: a micro-level analysis of regional economic development collaboration networks", Public Management Review, Vol. 72 No. 2, pp. 253-262.

Leadership and performance 
JPBAFM 32,2

Leithwood, K. (2019), "Characteristics of effective leadership networks: a replication and extension", School Leadership \& Management, Vol. 39 No. 2, pp. 175-197.

Mannozzi, S. and Visco Comandino, V. (1990), Le funzioni del governo locale in Italia. Verifica dell'effettività, Vol. 2, Giuffrè, Milano.

Martin, G.P., Currie, G. and Finn, R. (2008), "Leadership, service reform and public service networks: the case of cancer-genetics pilots in the English NHS", Journal of Public Administration and Theory, Vol. 19 No. 4, pp. 769-794.

May, P.J. and Winter, S.C. (2007), "Politicians, managers and street-level bureaucrats: influences on policy implementation", Journal of Public Administration Research and Theory, Vol. 19 No.3, pp. $453-476$.

McClelland, D.C. (1965), "N achievement and entrepreneurship: a longitudinal study", Journal of Personality and Social Psychology, Vol. 1 No. 4, pp. 389-392.

McGuire, M. and Silvia, C. (2009), "Does leadership in networks matter? Examining the effect of leadership behaviors on managers' perceptions of network effectiveness", Public Performance and Management Review, Vol. 33 No. 2, pp. 179-206.

McGuire, M. and Silvia, C. (2010a), "The effect of problem severity, managerial and organizational capacity and agency structure on intergovernmental collaboration: evidence from local emergency management”, Public Administration Review, Vol. 70 No. 2, pp. 279-288.

McGuire, M. and Silvia, C. (2010b), "Leading public sector networks: an empirical examination of integrative leadership behaviors", The Leadership Quarterly, Vol. 21 No. 2, pp. 264-277.

Neuliep, J.W. and Crandall, R. (1991), "Editorial bias against replication research", in Neuliep, J.W. (Ed.), Replication Research in the Social Sciences, Sage, Newbury Park, CA, pp. 51-69.

Powell, W.W. (1990), "Neither market nor hierarchy: network forms of organization", Organizational Behavior, Vol. 12, pp. 295-336.

Provan, K.G. and Huang, K. (2012), "Resource tangibility and the evolution of a publicly funded health and human services network", Public Administration Review, Vol. 72 No. 3, pp. 366-375.

Schalk, J., Torenvlied, R. and Allen, J. (2010), "Network embeddedness and public agency performance: the strength of strong ties in Dutch higher education", Journal of Public Administration Research and Theory, Vol. 20 No. 3, pp. 629-653.

Thomas, C.W. (2003), Bureaucratic Landscapes: Interagency Cooperation and the Preservation of Biodiversity, MIT Press, Cambridge, MA.

Tsang, E.W. and Kwan, K.M. (1999), "Replication and theory development in organizational science: a critical realist perspective", Academy of Management Review, Vol. 24 No. 4, pp. 759-780.

Turrini, A., Cristofoli, D., Frosini, F. and Nasi, G. (2010), "Networking literature about determinants of network effectiveness", Public Administration, Vol. 88 No. 2, pp. 528-500.

Waters, T. and Cameron, G. (2007), The Balanced Leadership Framework: Connecting Vision with Action, Mid-continent Research for Education and Learning (McREAL), ERIC, Denver.

Winch, P. (1958), The Idea of a Social Science, Routledge and Kegan Paul, London.

\section{Corresponding author}

Denita Cepiku can be contacted at: cepiku@economia.uniroma2.it

For instructions on how to order reprints of this article, please visit our website:

www.emeraldgrouppublishing.com/licensing/reprints.htm

Or contact us for further details: permissions@emeraldinsight.com 